\title{
Article
}

http://dx.doi.org/10.11646/phytotaxa.170.2.5

\section{Rhaponticoides gokceoglui (Asteraceae), a striking new species from Turkey}

\author{
İLKER ÇİNBILGEL ${ }^{1}$, ÖZKAN EREN ${ }^{2 *} \&$ HAYRİ DUMAN ${ }^{3}$ \\ ${ }^{1}$ Akdeniz University, Akseki Vocational School, Program of Hunting and Wildlife, 07630, Akseki, Antalya, Turkey; email: icinbilgel@ \\ akdeniz.edu.tr \\ ${ }^{2}$ Adnan Menderes University, Faculty of Arts and Sciences, Department of Biology, 09100, Aydin, Turkey; *corresponding author; \\ email: ozkaneren@adu.edu.tr \\ ${ }^{3}$ Gazi University, Faculty of Arts and Sciences, Department of Biology, 06500, Teknikokullar, Ankara, Turkey; \\ email:hduman@gazi.edu.tr
}

\begin{abstract}
Rhaponticoides gokceoglui is described as a species new to science. Its affinities within the genus are discussed. The new species is closely related to $R$. wagenitziana and $R$. aytachii from which we delimit it. Rhaponticoides gokceoglui is readily distinguished from those species by its entirely leafy stem, lacking a distinct appendage on phyllaries, ovate outer and ovateoblong to oblong middle phyllaries with a very narrow scarious margin, and inner phyllaries cucullate at apex only. Habitat conditions and conservation status of $R$. gokceoglui are considered. Finally, a distribution map and a key to the pinkishflowered species of Rhaponticoides in Turkey are provided.
\end{abstract}

Key words: Antalya, Compositae, taxonomy

\section{Introduction}

The genus Rhaponticoides Vaillant (1754: 165) was recently split from Centaurea Linnaeus (1753: 909). It occurs from Portugal and Morocco in the west to Mongolia in the east (Agababian 1997, Greuter 2003, Hellwig 2004, Greuter et al. 2005, Garcia-Jacas et al. 2006). If we exclude R. ruthenica (Lamarck 1785: 663) Agababian \& Greuter (2003: 61) which occurs over large areas, most of the representatives of the genus are narrow endemics (Wagenitz 1975, 1986, Eren 2007, Puntillo \& Peruzzi 2009, Tan et al. 2009, Doğu et al. 2009). In addition, there are only a few species such as $R$. wagenitziana (Bancheva \& Kit Tan 2009: 52) Agababian \& Greuter in Greuter \& Raus (2009: 337) which display disjunct distributions.

Recently, six species of Rhaponticoides were recognised in Turkey (Eren 2007). Eren provided the first key, as well as a distribution map of all Turkish representatives of the genus. Since that publication, R. aytachii Bağc1, Doğu \& Dinç in Doğu et al. (2009: 479) and R. wagenitziana were described (Tan et al. 2009, Greuter \& Raus 2009). The latter is described as a species new to science on the basis of plants collected in Bulgaria and Turkey, both formerly identified as R. amplifolia (Boissier \& Heldreich in Boissier 1856: 68) Agababian \& Greuter (2003: 60) in standard Floras of those countries and subsequent publications. This statement was no longer supported by Tan et al. (2009) who recognized the Turkish and Bulgarian populations as a distinct species. As indicated by Tan et al. (2009), $R$. amplifolia became endemic to the Peloponnese in southern Greece.

In early July 2010 a very striking species of Rhaponticoides, distinct from any other Turkish member of this genus, was collected in Suçıan mevkii, above Başlar village that belongs to İbradı district in the province of Antalya. The few plants gathered in early July 2010 were complemented by collections conducted in June and July 2011 from the same site. The population of Rhaponticoides from the Suçikan mevkii turned out to represent a hitherto unknown species related to $R$. wagenitziana and $R$. aytachii. Hence, this species is decribed here as new to science, bringing a total number of the species of Rhaponticoides known from Turkey to eight. Seven of those species, namely, $R$. gokceoglui sp. nov., R. aytachii, R. amasiensis (Bornmüller 1906: 54) Agababian \& Greuter (2003: 60), R. pythiae (Aznavour \& Bornmüller in Bornmüller 1927: 48) Agababian \& Greuter (2003: 61), R. iconiensis (Huber-Morath 1981: 77) Agababian \& Greuter (2003: 60), R. mykalea (Huber-Morath 1979: 370) Agababian \& Greuter (2003: 60), and $R$. hierroi Eren (2007: 15) are endemic to Turkey. Rhaponticoides wagenitziana is the only species which occurs both in Turkey and Bulgaria. The genus Rhaponticoides exhibits a high level of endemism in Turkey. 
2. Terminal segments of basal leaves broadly ovate; stem arachnoid below; all phyllaries or at least the middle and inner ones distinctly cucullate .............................................................................................................................. Rhaponticoides aytachii Terminal segments of basal leaves elliptic-lanceolate; stem puberulent below; phyllaries not cucullate.......

Rhaponticoides wagenitziana

\section{Specimens examined}

Rhaponticoides amplifolia:-GREECE. In montibus Kylleus faucibus Phlamburtya, T. Orphanides G 129 (E00394662, E00394663, type, photos!).

Rhaponticoides aytachii:-TURKEY. C4 Karaman: Sarıveliler, Dumlugöze köyü, bozulmuş Quercus ormanı, açıklıklar, 1000 -1050 m, 20 June 2007, S. Doğu 1398, Băgcı \& Dinç (GAZI, isotype).

Rhaponticoides wagenitziana:-BULGARIA. Toundzha Hills, Municipality of Elhovo, north of the village of Golyam Dervent, $42^{\circ} 01^{\prime} 18.1$ ” N, 2643'00.0” E, 348 m, 26 July 2006, S. Bancheva \& S. Stoyanov SB-07-06 (GAZI, isotype). TURKEY. A2 İstanbul: Aydos hill, on the slopes, 02 July 1974, Tuzlaci E 30115 (E00199159, E00474023, photos!).

\section{Acknowledgements}

We thank Dr. José L. Hierro (Argentina) for linguistic improvement of the text. Funding was provided by Akdeniz University Management Unit of Scientific Research Projects (project number 2008.03.0121.008).

\section{References}

Agababian, M. (1997) Centaurea subg. Centaurea (Compositae): Delimitation and distribution of sections and subsections. Lagascalia 19: 889-902.

Boissier, E. (1856) Diagnoses plantarum orientalium novarum, ser. 2, vol. 3. Lipsia [Leipzig], 177 pp.

Bornmüller, J. (1906) Centaurea amasiensis Bornm. (sect. Centaurium), florae Anatoliae species indescripta nova. Feddes Repertorium 3: $54-55$.

http://dx.doi.org/10.1002/fedr.19060032906

Bornmüller, J. (1927) Über eine neue Centaurea (C. pythiae Aznav. et. Bornm.) der Flora Kleinasiens. Mitteilungen des Thüringischen Botanischen Vereins, Neue Folge 37: 48-49.

Candolle, A.P. de (1838) Prodromus systematis naturalis regni vegetabilis, vol. 6. Treuttel \& Würtz, Paris, 687 pp. http://dx.doi.org/10.5962/bhl.title.286

Doğu, S., Bağcı Y. \& Dinç, M. (2009) Rhaponticoides aytachii sp. nov. (Asteraceae) from south Anatolia, Turkey. Nordic Journal of Botany 27: 479-482. http://dx.doi.org/10.1111/j.1756-1051.2009.00537.x

Eren, Ö. (2007) The genus Rhaponticoides Vaill. (Asteraceae) in Turkey: a new species and first key. Plant Systematics and Evolution 267: 13-23.

http://dx.doi.org/10.1007/s00606-007-0576-4

Garcia-Jacas, N., Uysal, T., Romashchenko, K., Suárez-Santiago, V.N., Ertuğrul, K. \& Susanna, A. (2006) Centaurea revisited: A molecular survey of the Jacea group. Annals of Botany 98: 741-753.

http://dx.doi.org/10.1093/aob/mcl157

Greuter, W. (2003) The Euro+Med treatment of Cardueae (Compositae) - generic concepts and required new names. Willdenowia 33: $49-61$.

Greuter, W., Agababian, M. \& Wagenitz, G. (2005) Vaillant on Compositae: Systematic impact and nomenclatural consequences. Taxon 54: 149-174.

http://dx.doi.org/10.2307/25065315

Greuter, W. \& Raus, T. (eds.) (2009) Med-Checklist Notulae 28. Willdenowia 39: 335-345.

http://dx.doi.org/10.3372/wi.39.39211

Greuter, W., Wagenitz, G., Agababian, M. \& Hellwig, F.H. (2001) Proposal to conserve the name Centaurea (Compositae) with a conserved type. Taxon 50: 1201-1205. 
http://dx.doi.org/10.2307/1224746

Hellwig, F.H. (2004) Centaureinae (Asteraceae) in the Mediterranean-history of ecogeographical radiation. Plant Systematics and Evolution 246: 137-162.

http://dx.doi.org/10.1007/s00606-004-0150-2

Huber-Morath, A. (1979) Novitiae Florae Anatolicae 13. Bauhinia 6: 370-371.

Huber-Morath, A. (1981) Novitiae Florae Anatolicae 14. Bauhinia 7: 77-80.

IUCN (2012) IUCN Red List Categories \& Criteria: version 3.1. IUCN Species Survival Commission. Gland, Switzerland \& Cambridge, UK.

Lamarck, J.B. de (1785) Encyclopédie méthodique: botanique, vol. 1(2). Paris, pp. 345-752.

Linnaeus, C. (1753) Species plantarum. L.Salvius, Holmia [Stockholm], 1200 pp.

Puntillo, D. \& Peruzzi, L. (2009) A new species of Rhaponticoides (Asteraceae) from Southern Italy. Folia Geobototanica 44: $191-197$. http://dx.doi.org/10.1007/s12224-009-9037-x

Tan, K., Bancheva, S., Vural, M. \& Strid, A. (2009) Centaurea wagenitziana (Asteraceae: Centaureinae), a new species from the Eastern Balkans. Phytologia Balcanica 15 (1): 51-58.

Vaillant, S. (1754) Neue Kennzeichen dreyer Classen von Pflanzen mit zusammengesetzeten Blumen, nämlich: der Cynarocephalarum, derer mit Artischockenhäuptern; Corymbiferarum, die zusammengesetzte, scheibenförmige Blumen tragen; Cichoracearum, wegwartartiger. Der Königl. Akademie der Wissenschaften in Paris. Anatomische, Chymische und Botanische Abhandlungen 5: 143-194, 333-377, 545-613, 697-750.

Wagenitz, G. (1975) Centaurea L. In: Davis, P.H. (ed.), Flora of Turkey and the East Aegean Islands, vol. 5. Edinburgh University Press, Edinburgh, pp. 465-585.

Wagenitz, G. (1986) Centaurea in South-West Asia: patterns of distribution and diversity. Proceedings of the Royal Society of Edinburgh 89B: 11-21.

http://dx.doi.org/10.1017/S0269727000008861 